\title{
EKSISTENSI PONDOK PESANTREN SALAFIYAH ROUDLOTUL MA'RIFAT DESA BORENG LUMAJANG DI ERA MODERN
}

\author{
Mohammad Fawaid \\ Sekolah Tinggi Agama Islam Denpasar, Indonesia \\ E-mail: fawaidalwan16@gmail.com \\ Hasan Farisi \\ Institut Agama Islam SyarifuddinLumajang, Indonesia \\ E-mail: farahhasan02@gmail.com
}

\begin{abstract}
Abstrak: Tulisan ini ingin mengungkap keberadaan lembaga pendidikan pesantren yang masih tetap berpegang teguh pada nilai-nilai tradisional,yakni pondok pesantren Roudlotul Ma'rifat di daerah Boreng Kabupaten Lumajang. Sebagaimana diketahui, artikel tentang adaptasi dan transformasi pesantren banyak dijumpai. Hanya saja, diakui atau tidak, masih terdapat beberapa pondok pesantren yang masih mempertahankan nilai-nilai tradisionalismenya di tengah maraknya tren perubahan pondok pesantren. Untuk melihat eksistensinya, peneliti melihat program pendidikan yang diterapkan di pondok pesantren Roudlotul Ma'rifat sebagai pesantren salaf, bagaimana kurikulum dikembangkan dan bagaimana pula pola kepemimpinan kiai di Pondok Pesantren tersebut. Penelitian ini menggunakan metode penelitian kualitatif dengan pendekatan fenomenologis. Teknik pengumpulan data yang dengan observasi dan wawancara serta dokumentasi. Penelitian dilakukan di bulan April tahun 2018. Kesimpulan penelitian ini menunjukkan bahwa dalam mempertahankan eksistensi pondok pesantren Roudlotul Ma'rifat, hal-hal yang dilakukan antara lain dengan mengikutsertakan santri persamaan paket $C$, mempertahankan khas budaya tradisional sebagai ciri pesantren, kurikulum yang diajarkan tetap mengacu pada tradisi klasik, serta gaya kepemimpinan kiai yang kharismatik dengan melakukan pengembangan Majelis Taklim Nariyah dan Keliling Kajian Hikam.
\end{abstract}

Kata Kunci: Eksistensi, Pesantren Salafiyah, Era Modern.

\section{Pendahuluan}

Perubahan masyarakat akibat modernisasi tidak dapat dihindari oleh sistem sosial manapun. Pada konteks keagamaan, kemunculan modernisasi Islam merupakan sebuah gerakan berkelanjutan yang juga dilatar belakangi oleh perubahan sosial masyarakat. Gerakan ini berlangsung melalui proses panjang yang didalamnya terjadi proses-proses negosiasi antara Islam dan nilai-nilai modernitas. ${ }^{1}$

\footnotetext{
${ }^{1}$ Arief Subhan, Lembaga Pendidikan Islam Indonesia Abad ke-20 (Jakarta: UIN Press dan Center for quality Development and Assurance, 2009), 30. 
Hal yang sama juga dialami di sektor pendidikan Islam yang berlangsung di Mesir, Turki, dan Arab Saudi. Ketiga negara ini, peranan negara ikut andil dalam proses modernisasi. Dalam kasus Mesir dan Turki, pendirian lembaga-lembaga pendidikan gaya Eropa yang mulanya khusus untuk pendidikan militer dan teknik dengan cepat diikuti dan diterapkan pada lembaga-lembaga pendidikan Islam lain.

Lembaga-lembaga modern itu dengan cepat menarik minat kalangan masyarakat muslim dari kelas sosial tertentu. Boleh dikatakan, lembag-lembaga pendidikan Islam lain di luar sekolah militer dan teknik terkondisikan untuk segera mengadopsi pengelolaan gaya Eropa, seperti penerapan kurikulum, ujian-ujian masuk dan ujian mata pelajaran dan sebagainya.

Arab Saudi memberikan pengaruh pada level berbeda. Posisinya sebagai lokasi dua kota suci, Mekkah dan Madinah, yang demikian istimewa dimata kaum muslim menjadikannya rujukan bagi Muslim Indonesia. Meskipun reformasi pendidikan yang berlangsung di Mekkah dan Madinah tidak sebesar di Mesir dan Turki, lembagalembaga pendidikan yang berkembang di tempat ini memberikan pengaruh penting dalam mendorong pertumbuhan madrasah tradisional di Indonesia, khususnya pesantren. $^{2}$ Dengan demikian, Indonesia-pun tak luput dari tuntutan melakukan modernisasi.

Dalam konteks Indonesia, pendidikan dianggap sebagai prasyarat dan kondisi yang mutlak bagi masyarakat untuk menjalankan program dan tujuan modernisasi pembangunan seperti halnya yang dialami pada masa Orde Baru. Pada masa ini, dinyatakan bahwa tanpa pembangunan yang memadai, sulit bagi masyarakat mencapai kemajuan. Karena itu banyak ahli pendidikan berpandangan bahwapendidikan kunci membuka pintu ke arah modernisasi. ${ }^{3}$ Dalam artian, pendidikan juga tidak akan dapat terhindar dari arus modernisasi sehingga pendidikan dituntut untuk menyesuaikan diri dengan perubahan masyarakat di tengah arus modernisasi.

Azyumardi Azra dalam hal ini menilai bahwa modernisasi Pendidikan Islam dirasa memiliki tawaran positif bagi pembangunan kembali peradaban Islam abad

2 Subhan, Lembaga Pendidikan Islam, 58.

${ }^{3}$ Subhan, Lembaga Pendidikan Islam, 30

174 | Tarbiyatuna: Jurnal Pendidikan Islam; Volume 11, Nomor 2, Agustus 2018 p-ISSN: 2085-6539; e-ISSN: 2242-4579 
pertengahan melalui media pendidikan, memberi tawaran dan solusi khususnya terkait lembaga-lembaga Pendidiakan Islam agar bisa tetap bertahan di era modern sekarang ini. ${ }^{4}$ Pandangan demikian setidaknya terlihat dari banyaknya lembaga pendidikan yang melakukan perubahan sesuai tuntutan dunia modern, termasuk di dalamnya banyak pesantren yang mengadopsi lembaga pendidikan formal, mulai dari SMP, SMA, bahkan sekolah kejuruan sebagai bentuk respon sekaligus strategi untuk mepertahankan eksistensi pesantren sebagai pendidikan Islam asli Indonesia.

Kondisi ini juga menuntut lembaga pendidikan Islam, pesantren tidak hanya dengan memanifestasikan nilai-nilai keislamannya ke dalam rangkaian upacaraupacara keagamaan, tetapi juga dituntut merumuskan kembali kerja-kerja agama yang patut dilakukan. ${ }^{5}$ Oleh karenanya, seiring berjalannya waktu pondok pesantren terbagi menjadi dua jenis antara lain pondok pesantren salaf dan pondok pesantren modern.

Pondok pesantren modern muncul karena memang ada tuntutan yang harus dipenuhi di era modern terutama ada integralisasi ilmu pengetahuan umum kedalam kurikulum pesantren yang pada awalnya cenderung dikotomis. Selain itu juga pondok pesantren modern muncul dikarenakan keberadaan pondok pesantren tersubordinasi oleh pendidikan yang mengadopsi kurikulum mata pelajaran umum karena memang tuntutan zaman yang sedemikian rupa, kemudian muncullah pondok pesantren yang hadir untuk mengintegrasikan antara ilmu agama dan ilmu umum. Sedangkan pondok pesantren yang tetap memegang teguh tradisi lama dalam proses ta'allum bahkan cenderung menutup diri terhadap perkembangan zaman bahkan pada tuntutan zaman di era modern dikenal dengan Pesantren Salaf.

Di era modern ini, eksistensi pondok pesantren salaf sebagai lembaga pendidikan mulai dipertanyakan. Tidak sedikit pondok pesantren yang enggan mengadopsi nilai-nilai kemodernan dapat bertahan. Namun demikian, hal ini pula yang menjadi ketertarikan tersendiri bagi penulis untuk meneliti pesantren Salaf, karena pada faktanya masih ada pesantren salaf hingga saat ini tetap diperhitungkan

${ }_{4}$ Azyumardi Azra, Penddidikan Islam, Tradisi dan Modernisasi di Tengah Tantangan Millenium III (Jakarta: Kencana Prenada Media Group, 2012), 34-35.

5 Abuddin Nata, Tokoh-tokoh Pembaruan Pendidikan Islam di Indonesia (Jakarta:Raja Grafindo, 2005), 5. 
keberadaannya oleh masyarakat, paling tidak masih diminati oleh masyarakat. Salah satu diantaranya adalah pondok pesantren Roudlotul Ma'rifat di Desa Boreng Lumajang.

Pondok pesantren ini adalah salah satu pondok pesantren yang ada di Lumajang yang masih bertahan dengan sistem pendidikan tradisional tanpa dicampur aduk dengan sistem pendidikan modern. Namun, meski pondok ini berpegang teguh terhadap tradisiolismenya, pondok pesantren Roudlotul Ma'rifat tetap eksis dan berdiri kokoh serta melakukan pembelajaran seperti biasanya hingga saat ini. Atas dasar inilah, penelitian ini akan mengkaji tentang eksistensi sistem pendidikan pesantren di era modern dengan study kasus di Pondok Pesantren Roudlotul Ma'rifat Boreng Lumajang.

\section{Definisi Konsep Eksistensi}

Eksistensi berasal dari bahasa Inggris yaitu excitence; dari bahasa latin existere yang berarti muncul, ada, timbul, memilih keberadaan aktual. Dari kata ex berarti keluar dan sister yang berarti muncul atau timbul. Beberapa pengertian secara terminologi, pertama, apa yang ada; kedua, apa yang memiliki aktualitas (ada), dan ketiga adalah segala sesuatu (apa saja) yang di dalam menekankan bahwa sesuatu itu ada. Berbeda dengan esensi yang menekankan kealpaan sesuatu atauapa sebenarnya sesuatu itu sesuatu dengan kodrat inherennya. ${ }^{6}$

\section{Pesantren}

Kata pesantren berasal dari kata santri dengan awalan pe dan akhiran an berarti tempat tinggal para santri. ${ }^{7}$ Atau pengertian lain mengatakan bahwa pesantren adalah sekolah berasrama untuk mempelajari agama Islam. ${ }^{8}$ Sumber lain menjelaskan pula bahwa pesantren berarti tempat untuk membina manusia

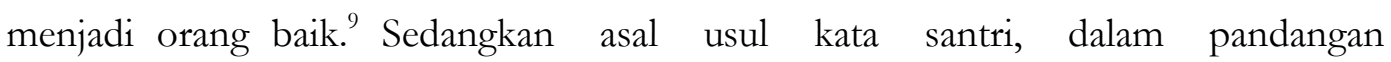

\footnotetext{
${ }^{6}$ Lorens Bagus, Kamus Filsafat (Jakarta: Gramedia Pustaka Utama, 2005), 183.

7 Clifford Geertz, "Abangan Santri; Priyayi dalam Masyarakat Jawa”, terj oleh Aswab Mahasun, Cet. II (Jakarta: Dunia Pusataka Jaya, 1983), 268. Dikutip oleh Yasmadi, Modernisasi Pesantren; Kritik Nurcholish Majid Terhadap Pendidikan Islam Tradisional (Jakarta: Quantum Teaching, 2005), 61.

8 Abu Hamid, "Sistem Pendidikan Madrasah dan Pesantren di Sul-Sel", dalam Taufik Abdullah (ed), Agama dan Perubahan Sosial (Jakarta: Rajawali Press, 1983), 329.

${ }_{9}^{9}$ Hamid, Sistem Pendidikan, 328.
} 
Nurcholish Madjid dapat dilihat dari dua pendapat. Pertama, pendapat yang mengatakan bahwa santri berasal dari perkataan sastri, sebuah kata dari bahasa Sanskerta yang artinya melek huruf. ${ }^{10}$ Di sisi lain, Zamakhsyari Dhofier berpendapat bahwa, kata santri dalam bahasa India berarti orang yang tahu buku-buku suci agama Hindu, atau seorang sarjana ahli kitab suci agama Hindu. Atau secara umum dapat diartikan buku-buku suci, buku-buku agama, atau buku-buku tentang ilmu pengetahuan. ${ }^{11}$ Kedua, pendapat yang mengatakan bahwa perkataan santri sesungguhnya berasal dari bahasa Jawa, yaitu dari kata cantrik, berarti seseorang yang selalu mengikuti seorang guru kemana guru itu pergi menetap. ${ }^{12}$

Pesantren adalah lembaga pendidikan tradisional yang lahir dan tumbuh berbarengan dengan datangnya Islam ke tanah Jawa. Dengan demikian, pesantren merupakan lembaga pendidikan tertua dan asli (indegenous) di masyarakat Indonesia. $^{13}$

Pondok pesantren menurut M. Arifin Suatu lembaga pendidikan agama Islam yang tumbuh serta diakui masyarakat sekitar, dengan sistem asrama (komplek) di mana santri-santri menerima pendidikan agama melalui sistem pengajian atau madrasah yang sepenuhnya berada di bawah kedaulatan dari leadership seorang atau beberapa orang kiai dengan ciri-ciri khas yang bersifat karismatik serta independen dalam segala hal. ${ }^{14}$

Sementara itu, KH Imam Zarkasyi mendefinisikan pondok pesantren sebagailembaga pendidikan Islam dengan sisitem asrama atau pondok, kiai sebagai figur sentralnya, masjid sebagai pusat kegiatan yang menjiwainya, dan pengajaran agama Islam sebagai kegiatan utamanya yang diikuti santri di bawah bimbingan kiai. $^{15}$

\footnotetext{
${ }^{10}$ Nurcholish Madjid, Bilik-bilik Pesantren; Sebuah Potret Perjalanan (Cet. I; Jakarta: Paramadina, 1977), 19.

11 Zamakhsyari Dofier, Tradisi pesantren: Studi pandangan Hidup Kiai dan Visinya Mengenai Masa Depan Indonesia (Jakarta: LP3ES, 2011), 18.

12 Nurcholish Madjid, Bilik-bilik Pesantren; Sebuah Potret Perjalanan, Cet. 1 (Jakarta: Paramadina, 1977), 20.

${ }^{13}$ Manfred Ziemik, Pesantren Dalam Perubahan Sosial, terj. Butche B Soendjoyo, Cet. I (Jakarta: P3M, 1986), 100 dan Kuntowijoyo, Paradigma Islam Interpretasi Untuk Aksi (Bandung: Mizan, 1990), 57.

${ }_{14}$ M.Arifin, Kapita Selekta Pendidikan (Islam dan Umum) (Jakarta: Bumi Aksara, 1991), 240.

15 Abdullah Syukri Zarkasyi, Gontor dan Pembaharuan Pendidikan Pesantren (Jakarta: PT. Raja Grafindo Persada, 2005), 4 .
} 
Menurut Manfred Ziemek, sebagaimana dikutip oleh Wahjoetomo menyebutkan bahwa pondok pesantren terdiri dari dua kata yaitu; pondok dan pesantren. Kata pondok berasal dari funduq (Arab) yang berarti ruang tidur atau wisma sederhana, karena pondok memang merupakan tempat penampungan sederhana bagi para pelajar yang jauh dari tempat asalnya. Sedangkan kata pesantren berasal dari kata santri yang diimbuhi awalan pedan akhiran an yang berarti menunjukkan tempat, maka artinya adalah tempat para santri. Terkadang juga dianggap sebagai gabungan kata sant (manusia baik) dengan suku kata tra (suka menolong), sehingga kata pesantren dapat berarti tempat pendidikan manusia baikbaik. $^{16}$

Di Indonesia pondok pesantren lebih dikenal dengan istilah Kutab merupakan suatu lembaga pendidikan Islam, yang di dalamnya terdapat seorang kiai (pendidik) yang mengajar dan mendidik para santri (anak didik) dengan sarana masjid yang digunakan untuk menyelenggarakan pendidikan tersebut, serta didukung adanya pondok sebagai tempat tinggal para santri. ${ }^{17}$

Pesantren atau pondok pesantren adalah lembaga pendidikan keagamaan Islam berbasis masyarakat yang menyelenggarakan pendidikan diniyah atau secara terpadu dengan jenis pendidikan lainnya. ${ }^{18}$

Dari beberapa pengertian pesantren di atas, dapat disimpulkan bahwa pondok pesantren adalah lembaga pendidikan Islam yang memiliki sistem asrama atau pondok sebagai tempat tinggal santri, figur kiai sebagai tokoh sentralnya, masjid sebagai sarana pendidikan, pengajarannya berorientasi pada pengajaran agama Islam dan ciri-ciri umum yang dimiliki pesantren adalah lembaga pendidikan yang asli Indonesia.

Ciri khas pesantren adalah terletak pada orientasinya untuk mendalami ilmu agama Islam dan mengamalkannya sebagai pedoman hidup keseharian (tafaqquh fiddin) dengan menekankan pentingnya moral dalam hidup bermasyarakat. Hal ini secara historis sangat berkaitan dengan peran yang dimainkan oleh lembaga

\footnotetext{
16 Wahjoetmo, Perguruan Tinggi Pesantren Pendidikan Alternatif Masa Depan (Jakarta: Gema Insani Press, 1997$), 70$.

${ }^{17}$ Hasbullah, Sejarah Pendidikan Islam di Indonesia, Cet.1 (Jakarta: PT. RajaGrafindo, 1995), 24.

18 Peraturan Pemerintah RI Nomor 55 tahun 2007 dalam Standar Nasional Pendidikan (Bandung: Fokus Media, 2008), 1 .

178 | Tarbiyatuna: Jurnal Pendidikan Islam; Volume 11, Nomor 2, Agustus 2018 p-ISSN: 2085-6539; e-ISSN: 2242-4579
} 
pesantren ini sejak mengalami Islamisasi yaitu selain sebagai lembaga pendidikan ia jugasebagai lembaga dakwah dan sosial keagamaan serta pusat gerakan pengembangan agama Islam. ${ }^{19}$ Secara historis pesantren ditempatkan pada posisi yang cukup istimewa dalam khazanah perkembangan sosial budaya masyarakat. Abdurrahman Wahid menganggap pesantren sebagai subkultur tersendiri dalam kehidupan masyarakat Indonesia. Sebagai buktinya dalam pandangan Abdurrahman Wahid, lima ribu pondok pesantren yang tersebar di enam puluh desa sebagai bukti bahwa pesantren sebagai sebuah subkultur. ${ }^{20}$

Dalam pandangan ilmu sosiologis, sebuah subkultur harus memiliki keunikankeunikan tersendiri dalam beberapa aspek yaitu, cara hidup yang dianut, pandangan hidup dan tata nilai yang diikuti, serta hierarki kekuasaan intern tersendiri yang ditaati sepenuhnya. Ketiga aspek ini terdapat dalam pesantren sehingga pesantren dirasa cukup untuk mengenakan predikat subkultur pada kehidupan. $^{21}$

Pesantren dianggap sebagai subkultur sebenarnya belum merata dimilki oleh pesantren sendiri. Terdapat kesulitan untuk melakukan identifikasi terhadap pesantren secara keseluruhan sebagai sebuah unit subkultur, karena tidak semua aspek kehidupan yang dimiliki pesantren berwatak subkultur. Bahkan beberapa aspek utama dari pesantren yang dianggap memiliki watak subkultur hanya dalam rangka ideal belaka, dan tidak ada pada kenyataannya. ${ }^{22}$

Setidaknya ada dua tujuan terbentuknya pondok pesantren, yakni dapat dilihat dari tujuan umum, dan tujuan khusus.Tujuan umum pesantren adalah membimbing anak didik agar memiliki kepribadian sesuai dengan ajaran Islam dan mampu menjadi muballigh Islam dalam masyarakat melalui ilmu dan amalnya. Sedangkan tujuan khusus pesantren adalah membimbing dan mempersiapkan santri untuk menjadi manusia yang alim dalam ilmu agamanya dan mampu mengamalkan ilmunya dalam kehidupan masyarakat. ${ }^{23}$

\footnotetext{
19 Rofiq Nurhadi, "Sistem Pendidikan Pesantren di Tengah Arus Demokratisasi", Studi An-Nur, vol. II, No. 3 (Yogyakarta: Sekolah Tinggi Ilmu Al-Qur'an An-Nur, 2005), 51.

20 Sulthon Masyhud, Manajemen Pesantren, Cet.2 (Jakarta: Diva Pustaka, 2005), 10.

21 Abdurrahman Wahid, Menggerakekan Tradisi: Esai-Esai Pesantren (Yogyakarta: PT LKiS, 2001), 10.

22 Abdurrahman Wahid, Bunga Rampai Pesantren (Jakarta: CV Dharma Bhakti, 1987), 9.

${ }^{23}$ HM Arifin, Kapita Selekta Pendidikean Islam dan Umum (Jakarta: Bumi Aksara, 1995), 248.
} 
Melihat dari tujuan tersebut, sangat jelas bahwa pesantren merupakan lembaga pendidikan Islam yang berusaha membentuk kader-kader muballigh yang dapat meneruskan misi dalam dakwah Islam, di samping itu diharapkan setelah santri belajar di pesantren dapat menguasai ilmu-ilmu keIslaman yang telah diajarkan oleh kiai dan dapat mengamalkan ilmunya dalam masyarakat.

\section{Sistem Pendidikan}

Sistem pendidikan sejatinya adalah satu kesatuan yang terdiri atas komponenkomponen atau elemen-elemen atau unsur-unsur yang mempunyai hubungan fungsional yang teratur, tidak sekedar acak yang saling membantu untuk mencapai suatu hasil, sebagai contoh, tubuh manusia sebagai sistem. ${ }^{24}$ Sedangkan pendidikan adalah usaha sadar dan terencana untuk mewujudkan suasana belajar dan proses pembelajaran agar pesrta didik secara aktif mengembangkan potensi dirinya untuk memiliki kekuatan spiritual keagamaan, pengendalian diri, kepribadian, kecerdasan, akhlaq mulia, serta keterampilan yang diperlukan dirinya, masyarakat, bangsa dan negara. ${ }^{25}$ Jadi, sistem pendidikan adalah totalitas interaksi dari seperangkat unsurunsur pendidikan yang bekerja sama secara terpadu, dan saling melengkapi satu sama lain menuju tercapainya tujuan pendidikan yang telah cita-cita bersama para aktornya.

Lebih lanjut, rincian komponen-komponen dalam pendidikan yang juga disebut sebagai sistem pendidikan dapat ditelusuri dalam peraturan pemerintah tentang Standar Nasional Pendidikan (SNP), berdasarkan Undang-Undang Nomor 20 tahun 2003 sebagai berikut:

1. Standar Kompetensi kelulusan: adalah kualifikasi kemampuan lulusan yang mencakup sikap, pengetahuan, dan ketrampilan;

2. Standar Isi: adalah ruang lingkup materi dan tingkat kompetensi yang dituangkan dalam kriteria tentang kompetensi tamatan, kompetensi bahan kajian, kompetensi mata pelajaran, dan silabus pembelajaran yang harus dipenuhi oleh peserta didik pada jenjang dan jenis pendidikan tertentu;

${ }^{24}$ Zahara Idris, Pengantar Pendidikan (Jakarta: PT. Gasindo, 1992), 37.

${ }^{25}$ Departemen Pendidikan Nasional. 2003, Undang-Undang Republik Indonesia Nomor 20

180 | Tarbiyatuna: Jurnal Pendidikan Islam; Volume 11, Nomor 2, Agustus 2018 p-ISSN: 2085-6539; e-ISSN: 2242-4579 
3. Standar Proses: adalah standar nasional pendidikan yang berkaitan dengan pelaksanaan pembelajaran pada satu satuan pendidikan untuk mencapai standar kompetensi kelulusan;

4. Standar pendidik dan tenaga kependidikan: adalah kriteria pendidikan prajabatan dan kelayakan fisik maupun mental, serta pendidikan dalam jabatan;

5. Standar sarana dan prasarana: adalah standar nasional pendidikan yang berkaitan dengan kriteria minimal tentang ruang belajar,rempat berolahraga, tempat beribadah, perpustakaan, laboratorium, bengkel kerja, tempat bermain, tempat berkreasi dan berekreasi, serta sumber belajar lain yang diperlukan untuk menunjang proses pembelajaran, termasuk penggunaan teknologi informasi dan komunikasi;

6. Standar Pengelelolaan: adalah standar nasional pendidikan yang berkaitan dengan perencanaan, pelaksanaan, dan pengawasan kegiatan pendidikan pada tingkat satuan pendidikan, kabupaten/kota, provinsi, atau nasional agar tercapai efisisensi dan efektifitas penyelenggaraan pendidikan;

7. Standar Pembiayaan: adalah standar yang mengatur komponen dan besarnya biaya operasi satuan pendidikan dan besarnya biaya operasi satuan pendidikan yang berlaku selama satu tahun;

8. Standar Penilaian Pendidikan: adalah standar nasional pendidikan yang berkaitan dengan mekanisme, prosedur, dan instrumen penilaian hasil belajar peserta didik. $^{26}$

Dari uraian di atas tentang Sistem Pendidikan Nasional, secara sederhana dapat dipahami pula sebagai segala hal yang berkaitan satu sama lainnya dalam pelaksanaan pendidikan hingga mencapai target tujuan yang ingin dicapai. Di situlah kemudian Sistem Pendidikan dapat berupa kurikulum, evaluasi, prosedur pelaksanaan pengajar dan sejenisnya.

\section{Modernisasi}

${ }^{26}$ Standar Nasional Pendidikan (Bandung: Fokusmedia, 2008), 1. 
Secara bahasa modernisasi berasal dari kata modern yang berarti terbaru atau mutakhir. Makna lain dari sikap dan cara berpikir sesuai dengan perkembangan zaman. Kemudian mendapat imbuhan isasi yang mengandung proses. Pengertian modernisasi suatu proses pergeseran sikap dan mentalitas sebagai warga masyarakat untuk bisa hidup sesuai dengan perkembangan zaman. ${ }^{27}$ Modern berarti mutakhir, atau sikap dan cara berpikir serta bertindak sesuai dengan tuntutan zaman. Sedangkan Modernisasi adalah proses pergeseran sikap dan mentalitas sebagai warga masyarakat untuk dapat hidup sesuai tuntutan hidup masa kini. $^{28}$

Istilah modern berasal dari bahasa Latin akhir abad kelima masehi, yaitu modernus, yang digunakan untuk membedakan keadaan orang Kristen dengan orang Romawi dari masa pagan yang telah lewat. Sesudah itu, istilah tersebut digunakan untuk menempatkan keadaan masa kini dalam kaitannya dengan berlalunya zaman purbakala, yang sering muncul kembali selama periode tersebut di Eropa. Dalam hubungannya dengan akal, agama dan apresiasi estetik, dinyatakan bahwa zaman modern merupakan zaman yang lebih maju, lebih baik dan memiliki kebenaran yang lebih banyak dari pada zaman kuno (zaman sebelumnya). ${ }^{29}$

Peter Sztompka menyatakan bahwa modernisasi merupakan proses perubahan sistem sosial, ekonomi dan politik yang telah maju di Eropa Barat dan Amerika dari abad ketujuh belas hingga kesembilan belas, dan kemudian menyebar ke negara-negara lain, seperti Amerika Selatan, Asia dan Afrika dari abad ke-19 hingga ke-20. ${ }^{30}$

Wilbert Moore dalam pendapat lain menyatakan bahwa modernisasi adalah transformasi total masyarakat tradisional atau pra-modern ke tipe masyarakat teknologi dan organisasi sosial yang menyerupai kemajuan dunia Barat yang ekonominya makmur dan situasi politiknya stabil. ${ }^{31}$

${ }_{27}$ Departemen Pendidikan dan Kebudayaan, Kamus Besar Bahasa Indonesia (Jakarta: Balai Pustaka, 1989), 589.

28 Departemen Pendidikan dan Kebudayaan, Kamus Besar Bahasa Indonesia, 589.

29 Bryan Turner, Teori-Teori Sosiologi Modernitas dan Pos modernitas, terj. Imam Baihaqi (Yogyakarta: Pustaka Pelajar, 2003), 71.

30 Peter Sztmpka, Sosiologi Perubahan Sosial, terj. Alimandan (Jakarta: Prenada Media, 2005), 152.

31 Sztmpka, Sosiologi, 153.

182 | Tarbiyatuna: Jurnal Pendidikan Islam; Volume 11, Nomor 2, Agustus 2018 p-ISSN: 2085-6539; e-ISSN: 2242-4579 
Dari masalah ini dapat disimpulkan bahwa modernisasi adalah perubahan sistem sosial masyarakat tradisional menjadi sistem yang menyerupai kemajuan dunia barat.

\section{Syarat Modernisasi}

Modernisasi tidak sama dengan reformasi yang menekankan pada faktorfaktor rehabilitasi. Modernisasi preventif dan konstruktif agar proses tersebut tidak mengarah pada angan-angan sebaliknya modernisasi harus dapat memproyeksikan kecendrungan yang ada dalam masyarakat ke arah waktu-waktu yang mendatang. Teori yang digagas Soerjono Soekanto memiliki beberapa syarat yaitu :

1. Cara berpikir yang ilmiah (scientific thinking).

2. Sistem administrasi yang baik, yang benar-benar mewujudkan birokrasi.

3. Adanya sistem pengumpulan data yang baik dan teratur serta terpusat.

4. Penciptaaan iklim favourable dari masyarakat terhadap modernisasi dengan cara penggunaan alat-alat komunikasi massa.

5. Tingkat organisasi yang tinggi.

6. Sentralisasi wewenang dalam pelaksanaan perencanaan sosial. ${ }^{32}$

\section{Ciri-ciri modernisasi}

Modernisasi ini dapat terjadi dan dialami suatu kelompok masyarakat disebuah negara, secara bertahap dan merata. Karena arus modernisasi masuk secara bertahap, maka masyarakat akan mudah untuk mengenali ciri-ciri dari modernisasi itu sendiri, karena modernisasi merupakan modal kehidupan.

Berikut ciri- ciri dari modernisasi :

1. kebutuhan materi dan persiangan kebutuhan manusia.

2. adanya kemajuan teknologi.

3. modernisasi membawa kemudahan .

4. keinginan masyarakat dapat terpenuhi.

5. modernisasi memenculkan teori kehidupan yang baru. 
6. perubahan mekanisme pada masyarakat.

7. perhatian religius yang teralihkan. ${ }^{33}$

\section{Pondok Pesantren dan Tantangan modernisasi}

Pesantren sejak awal berdirinya tidak pernah diam dalam menghadapi problem sosial keagamaan. Peran pesantren bahkan tidak cukup bila dikatakan hanya sebatas skala regional. Aktifitas pesantren dalam merespon persoalan global telah dibuktikan semenjak masa-masa awal kejayaannya. Keterlibatan pesantren dalam dunia global telah dibuktikan oleh fakta sejarah yang tidak mungkin utuk dinafikan. Respon pesantren terhadap permasalahan global misalnya:

Pertama, pesantren pernah merespon tantangan global dalam menghadapi kolonialisme bangsa barat yang ketika itu sedang melakukan ekspansi ke negeri-negeri jajahannya, termasuk Indonesia. Lembaga pendidikan pesantren dimasa kolonialisme tetap hidup dan berkembang di atas kekuatan sendiri. Bahkan lembaga ini bagi pemerintah Belanda, bukan saja dipandang tidak bermanfaat bagi tujuan-tujuan kolonial, akan tetapi dipandang sebagai lembaga yang sangat berbahaya dan mengancam upaya kolonialisme.

Pandangan bangsa Belanda itu bukan tanpa sebab, karena ketika itu lembaga pesantren merupakan tempat persemaian yang amat subur bagi kaderkader pejuang melawan praktik penjajahan. Atas dasar pandangan tersebut, maka ketika itu pesantren mengalami tekanan yang sangat berat, bahkan dianggap oleh kolonial barat sebagai sarang pemberontak dan ancaman bagi kenyamanan kekuasaan kolonial di bumi Indonesia, khususnya. Hal itu terjadi karena para Kiai di pesantren selalu memberikan pengajaran kepada para santrinya untuk menintai tanah air (bub al wathan), serta menanamkan sikap patriotik, meski awalnya merupakan lembaga pendidikan dalam bidang keagamaan. ${ }^{34}$

Kedua, kalangan pesantren yang tergabung dalam komite hijaz yang dipelopori elit ulama pernah memperjuangkan hukum bermadzhab kepada pemerintah Arab Saudi yang menganut faham Wahabi. Komite ini mengusulkan kepada

\footnotetext{
33 Soekanto, Sosiologi Suatu, 386-387.

34 Mahpuddin Noor, Potret Dunia Pesantren, Lintas Sejarah, Perubahan, dan Perkembangan Pondok Pesantren (Bandung: Humanioria, 2006), 12.

184 | Tarbiyatuna: Jurnal Pendidikan Islam; Volume 11, Nomor 2, Agustus 2018 p-ISSN: 2085-6539; e-ISSN: 2242-4579
} 
pemerintah Saudi agar memberikan kebebasan kepada praktik bermadzhab dalam menjalankan agama. Komite internasional ini dibentuk di Surabaya, yang dihasilkan melalui forum rapat yang dihadiri ulama pesantren, berbarengan dengan lahirnya keputusan mereka mendidikan Jam'iyyah Nahḍatul Ulama (NU). ${ }^{35}$ Dua peristiwa tentang peran Ulama pesantren ini mencerminkan bahwa dalam kondisi perubahan apapun, dalam skala lokal, regional maupun global, pesantren telah berusaha untuk mampu menjawab tantangan yang berkembang dan memberikan layanan terbaik bagi masyarakat.

Peran dan fungsi pesantren tersebut seharusnyaa terus dipertahankan di saat umat Islam sekarang ini menghadapi dua tantangan besar, yaitu globalisasi neo-liberalisme yang turut mengendalikan tatanan dunia baru dan munculnya modelmodel Islam berjenis lain yang dikenal fundamentalisme-ekstrim, dengan watak yang keras, kurang toleran dan tidak ramah dalam mensikapi persoalan yang muncul dan dihadapi bangsa. ${ }^{36}$ Globalisasi neo liberalisme merupakan lanjutan dari kapitalisme yang saat ini telah diadopsi oleh sebagian besar negara-negara berkembang, termasuk Indonesia. Dampak dari neo-liberalisme ini adalah munculnya krisis moneter berkepanjangan, meningkatnya angka penganguran dan kemiskinan yang dialami oleh sebagian besar umat Islam yang berprofesi sebagai petani dan buruh tani dipedesaan, nelayan kecil dan pedagang dengan modal pas-pasan. Sehingga mau tidak mau mereka harus mengamati akumulasi kemiskinan laten, yang subur oleh minimnya akses tanah dan kejijakan pembangunan yang berorientasi kepada teknologi tinggi padat modal. Dalam proses pembangunan, mereka mengalami marjinalisasi secara struktural karena terknologi tinggi dibangun dengan terburu-buru dan mengandalkan hutang luar negeri, sementara rakyat kecil cenderung diterlantarkan. ${ }^{37}$

Pesantren dalam menghadapi tantangan neo-liberalisme harus mampu mendesain secara aktif dan kreatif serta memberikan strategis dakwah dengan

${ }^{35}$ Nur Kholik Ridwan, NU dan Neoliberalisme; Tantangan dan Harapan Menjelang Satu Abad (Yogyakarta, LKiS, 2008), 1.

36 Ridwan, NU dan Neoliberalisme, 2.

${ }^{37}$ Jeremy Seabrook, Kemiskinan Global; kegagalan Model Ekonomi Neo-Loberalisme, terj. Darmawan (Yogyakarta: Resist Book, 2006). 
langkah -langkah yang lebih taktis, misalnya melakukan dakwah dengan melakukan program-program perberdayaan ekonomi dan pendampingan masyarakat agar diperoleh kondisi masyarakat yang bisa berubah di atas kemandiriannya, bertindak atas dasar perencanaannya, bukanatas dasareksploitasi pasar yang digerakkan kepentingan-kepentingan pihak tertentu.

Di sisi lain, pada tingkat internal agar tetap eksis, seluruh pesantren di era global juga seharusnya mempersiapkan diri secara memadahi. Pesantren hendaknya dapat terlibat dalam aktifitas-aktifitas sosial-kemanusiaan, menjadi agen perubahan sosial (agent of change). ${ }^{38}$ Oleh sebab itu, sudah saatnya pesantren yang dulunya sebagai agent pendalaman ilmu-ilmu agama, sekarang dikembangkan sebagai pusatpusat pengembangan teknologi tepat guna bagi masyarakat pedesaan, pusat penyelamatan dan pelestarian lingkungan hidup, dan yang lebih penting dari semua itu adalah pusat pemberdayaan ekonomi bagi kesejahteraan masyarakat secara luas.

Berdasarkan indikator tersebut, dalam melakukan dakwahnya, pesantren seharusnya tidak hanya berkutat pada masalah internal (pengajaran dan pendidikan) kepada para santrinya, melainkan harus berdakwah secara aktif dalam menekankan pada upaya-upaya penyelesaian masalah yang berkembang di tengah-tengah kehidupan sosial kemasyarakatan. Dalam tugasnya melakukan pemberdayaan (empowerment) dan transformasi sosial, pesantren yang menempati posisi yang sangat penting itu tidak bisa terlepas dari peran substansial dalam dakwah Islam, yang antara lain berperan sebagai: fasilitator, mobilisator, agent of change, dan center of excellence. ${ }^{39}$ Sedangkan Sahal Mahfudh, memberikan rambu-rambu bagi pengelola pesantren, yakni apabila pesantren ingin mempertahankan potensinya sebagai lembaga pendidikan keagamaan (tafaqquh Fi al din), maka pesantren harus melengkapi dirinya dengan tenaga-tenaga yang terampil mengelola sumber daya di lingkungannya. ${ }^{40}$ Berbagai pandangan tersebut merupakan salah

38 Azyumadi Azra, Pendidikan Islam, Tradisi dan modernisasi menuju Millenium Baru (Jakarta: Logos Wacana Ilmu, 2000), 3.

${ }^{39}$ Sa'id Aqiel Siradj, Pesantren Masa Depan (Bandung :Pustaka Hidayah, 1999$), 56$.

40 Sahal Mahfudh, Nuansa Fiqh Sosial, Yogyakarta, LKiS, 2003. Lihat pula, Pesantren Mencari Makna (Jakarta: Pustaka Ciganjur), 1999.

186 | Tarbiyatuna: Jurnal Pendidikan Islam; Volume 11, Nomor 2, Agustus 2018 p-ISSN: 2085-6539; e-ISSN: 2242-4579 
satu jawaban bagi prediksi terhadap masa depan pesantren, termasuk pula adanya pandangan bahwa pesantren dewasa ini sedang mengalami krisis dan kemunduran.

Di era global seperti sekarang ini sering muncul berbagai gerakan Islam yang mempunyai jenis lain dengan wataknya yang ekstrim, keras dan kurang toleran dalam menghadapi perbedaan, hal tersebut pada gilirannya menjadi tantangan dakwah yang harus dihadapi oleh pesantren. Tantangan itu kini muncul kembali dalam bentuk-bentuk Islam lain yang sama radikalnya dalam praktik sosio-religiuskultural. Bahkan tidak hanya itu, di era reformasi, wajah radikalisme pesantren yang belum pernah muncul sejak dipelopori oleh Walisongo pada abad ke-15, kini mulai tertandingi oleh lahirnya pesantren-pesantren yang mempunyai ideologi fundamentalisme.

Pesantren-pesantren yang memiliki watak demikian, bukan hanya memproduk wacana, tetapi sudah bergerak jauh dalam bentuk gerakan dan aksi massa yang mengintrodusir kekerasan, misalnya melakukan aksi pengeboman, main hakim sendiri, dan yang lebih penting lagi adalah aksi menghidupkan kembali gerakan Negara Islam Indonesia dengan memperlakukan syari'at islam dalam level Negara. ${ }^{41}$

Gudang-gudang tradisi masyarakat pesantren kini tidak luput dari hantaman gelombang ideologi yang mengatasnamakan jihad. Selain melakukan pengeboman dan aksi-aksi kekerasan, kelompok Islam jihadi secara massif berani mempengaruhi masyarakat melalui penguasaan pendidikan di masjid-masjid umat awam, yang semula menjadi tempat berdakwah kalangan Islam pesantren, khususnya NU dan Muhammadiyah. Begitu pula mereka berani melakukan depat publik yang disiarkan langsung oleh media massa.

Perlawanan paling fenomenal dari kelompok Islam purifis ini adalah kebangkitan kembali Islam yang menjelma dalam bentuk pencarian khazanah Islam klasik yang digunakan sebagai modal dalam kehidupan sosial, politik dan keagamaan. Pencarian tersebut merupakan ciri pemikiran kebangkitan Islam, terutama sekali berlaku dilingkungan kelompok yang memiliki ideologi fundamentalisme-ekstrim. Sayangnya pencarian itu sering kali menghadirkan

${ }^{41}$ Nur Khalik Ridwan, Regenerasi NII; Membedah Jaringan Islam Jihadi di Indonesia (Jakarta, Erlangga, 2008). 
pemikiran Islam dalam perspektif tafsir monolitik, bahkan tidak jarang berubah menjadi gerakan Islam yang terjebak dalam manipulasi teks sebagai alat untuk membenarkan berbagai tindakan melawan hukum. ${ }^{42}$

Pendidikan pesantren yang berkarakter dan berideologi radikalisme ini jelas bertentangan dengan tujuan utama dakwah bagi pesantren yang didirikan Walisongo, yakni berdiri tegak di atas sendi moralitas dan budaya asli bangsa Indonesia. Tujuan itu mampu mencetak kader ulama yang mempunyai wawasan luas dengan karakter ramah lingkungan. Sedangkan ciri yang dikedepankan oleh kalangan masyarakat Islam pesantren adalah moderatisme, dengan tidak pernah mengorbankan substansi Islam. Dengan mempertahankan dan memperlakukan tradisi diharapkan keberadaannya mampu menjawab tantangan modersisasi, dengan pemaknaan bahwa tradisi ada sesuatu yang selalu hadir dan menyertai kekinian kita yang berasal dari masa lalu kita atau masa lalu orang lain. Tradisi adalah titik temu antara masa lalu dengan masa kini. ${ }^{43}$

Dari sini dapat disimpulkan bahwa pesantren bukan hanya menghadapi masalah modernisasi di sektor ekonomi, tapi juga termasuk akibat-akibat yang menjadi dampak modernisasi, seperti munculnya munculnya aliran-aliran ekstrem di agams atau radikalisme agama.

Oleh karenanya, Pesantren di era global sudah seharusnya mulai bergerak melakukan introspeksi terhadap ajaran dasarnya, sebagai upaya menghadapi tantangan radikalisme dan kompetisi dunia modern, sehingga pesantren tidak terlalu kaku dalam mentransfer serta mensikapi perubahan-perubahan sosial. Pendidikan pesantren harus dikembalikan kepada format awalnya secara kritis, yakni sebagai pusat pendidikan yang mampu beradaptasi dengan budaya lokal, tanpa harus saling menafikan.

\section{Metodologi}

Penelitian ini menggunakan metode penelitian kualitatif yaitu prosedur penelitian yang menghasilkan data diskriptif dengan pendekatan fenomenologis yang

42 Abdurrahman Kasdi, Fundamentalisme Islam Timur Tengab; Akar Teologi, Kritik. W acana dan Pilotisasi Agama, dalam Tanwir Al Afkear, No. 13, tahun 2002.

${ }^{43}$ Muhammaad Abed Al-Jabiri, Post Tradisionalisme Islam, tejr. Ahmad Baso (Yogyakarta; LKiS, 2000), 24

188 | Tarbiyatuna: Jurnal Pendidikan Islam; Volume 11, Nomor 2, Agustus 2018 p-ISSN: 2085-6539; e-ISSN: 2242-4579 
berarti suatu penelitian yang berusaha memahami arti peristiwa dan kaitannya terhadap orang-orang biasa dalam situasi tertentu ${ }^{44}$. Teknik pengumpulan data yang digunakan: observasi yakni studi yang disengaja dan sistematis tentang fenomena sosial dan gejala-gejala alam dengan jalan pengamatan dan pencatatan, ${ }^{45}$ wawancara yaitu proses tanya jawab yang berlangsung secara lisan oleh dua orang atau lebih yang bertatap muka secara langsung informasi-informasi akan keterangan-keterangan, ${ }^{46}$ dan dokumentasi adalah mencari data mengenai hal-hal atau variabel yang berupa catatan, transkrip, buku atau surat kabar dan majalah. ${ }^{47}$ Penelitian dilakukan di bulan April tahun 2018.

\section{Strategi Kebertahanan Pesantren Roudlotul Ma'rifat}

Dalam menghadapi tantangan modernisasi, pondok pesantren Roudlatul Ma'rifat menjalankan hal-hal sebagai berikut:

1. Akselerasi dan sinergi dengan lembaga pendidikan formal

Untuk mempertahankan sistem salafiyah, pondok pesantren Roudlotul Ma'rifat melakukan banyak strategi untuk bisa bertahan dan beradaptasi dengan perkembangan zaman. KH. Ach. Umar Faruq, yang sering dipanggil Gus Mama', mengatakan:

"Pondok Pesantren Roudlotul Ma'rifat dapat bertahan dan mempertahankan diri sebagai pesantren tradisional di era modern adalah dengan mengikutsertakan santri pada persamaan MTs/SMP di SMP Negeri 1 Sukodono, dari yang tingkat SMP/MTs jika menginginkan untuk meneruskan ke tingkat selanjutnya maka kami mengijinkan untuk melanjutkan melalui paket C di Tunjung Randuagung." 48

Firdaus salah satu pengajar di Pondok Pesantren Roudlotul Ma'rifat, beliau mengatakan:

"salah satu cara mempertahankan diri sebagai pesantren tradisional di era modern adalah dengan melakukan kerja sama dengan pihak Diknas Kabupaten Lumajang, agar para santri dapat melanjutkan sekolahnya dan

\footnotetext{
${ }^{44}$ Lexy J Moeleong, Metode penelitian kualitatif (Bandung: Remaja Rosda Karya Offest, 1994), 42.

45 Kartono kartini, Metodologi Penelitian Sosial (Bandung: Bumi Aksara, 1996), 157.

46Margono, S, Metodologi Penelitian Pendidikan (Jakarta: Rineka Cipta, 2000), 79.

${ }^{47}$ Suharmisi Arikunto, Prosedur Penelitian (Jakarta: PT. Rineka Cipta, 2003), 234.

48 Umar Faruq, Wawancara, Pengasuh Pondok Pesantren Roudlotul Ma'rifat, 06 April 2018.
} 
pondok pesantren disini dapat mempertahankan eksistesinya sebagai pesantren tradisional." ${ }^{49}$

Khomsin, salah satu pengajar di pondok pesantren Roudlotul Ma'rifat, mengatakan bahwa:

'Dengan mengadakan program dengan mengikut sertakan santri pada persamaan MTs/SMP dan paket C, santri dapat terus melanjutkan pendidikan yang diwajibkan pemerintah, namun juga tidak meninggalkan kewajiban sebagai mahkluk Allah yang telah dijadikan sebagai kholifah di bumi. Dengan tetap mengemban amanahnya yakni dengan tetap berada pada garis lurus yang telah ditetapkan oleh Allah dengan mempelajari syari'at Islam, yang program pengajian kitabnya maupun keseharian santri telah tersusun, dan tidak meninggalkan kesalafan dari Pondok Pesantren Roudlotul Ma'rifat. ${ }^{50}$

Penjelasan tersebut di atas menunjukkan bahwa pondok pesantren Roudlotul Ma'rifat dalam mempertahankan eksistensi tradisionalnya adalah dengan mengikutsertakan santri pada persamaan MTs/SMP dan paket C.Persamaan MTs/SMP adalah kelompok belajar yang biasanya juga disebut paket B, yaitu jalur kusus pendidikan nonformal yang difasilitasi oleh pemerintah untuk siswa yang belajarnya tidak melalui jalur sekolah. Santri pondok pesantren Roudlotul Ma'rifat adalah santri yang tidak menempuh pendidikan jalur pendidikan secara formal.

Paket C adalah bagian dari Ujian Nasional Pendidikan kesetaraan, yaitu ujian yang diberikan kepada mereka yang tidak mengikuti pendidikan formal tapi ingin ijazah setara SMA. Paket C tidak ada batasan umur tertentu dan siapa saja bisa mengikutinya, dari yang tidak pernah sekolah atau yang putus sekolah sampai mereka yang sudah diusia kerja tapi belum punya ijazah, semuanya boleh ikut. Santri Pondok Pesantren Roudlotul Ma'rifat mengikui program ini karena basis pondok pesantren Roudlotul Ma'rifat adalah salafiyah. Pondok pesantren ini mempertahankan kesalafan sekalipun saat ini adalah modern, karena ingin menjaga keaslian pesantren.

2. Mempertahankan Nilai-Nilai Tradisional

${ }^{49}$ Firdaus, Wawancara, Ustadz Pondok Pesantren Roudlotul Ma'rifat, 06 April 2018.

${ }^{50}$ Khomsin, Wawancara, Ustadz Pondok Pesantren Roudlotul Ma'rifat, 07 April 2018.

190 | Tarbiyatuna: Jurnal Pendidikan Islam; Volume 11, Nomor 2, Agustus 2018 p-ISSN: 2085-6539; e-ISSN: 2242-4579 
Dalam mempertahankan eksistensinya, pondok pesantren Pondok Pesantren Raudlotul Ma'rifat justru mempertahankan pola hidup dan kebiasaan tradisional. Fathul Huda, salah satu pengajar pondok pesantren Raudlotul Ma'rifat mengatakan:

“salah satu upaya Pondok Pesantren Raudlotul Ma'rifat dalam mempertahankan eksistensi adalah dengantidak menghilangkan budaya tradisional, seperti halnya santri masak sendiri dengan menggunakan kayu bakar.Bagi kami, menjaga tradisi ini sama dengan kembali ke sejarah awal berdirinya pesantren. Kami percaya Allah akan tetap memberikan yang terbaik." ${ }^{51}$

Hal yang sama juga disampaikan oleh Rozy, yang juga salah satu pengajar di pondok pesantren tersebut. Ia mengatakan:

"pada pondok pesantren yang lain sebagian besar budaya santri dahulu atau ketradisionalannya sudah hampir punah, bahkan ada yang sangat punah. Disini, kami berupaya untuk tidak menghilangkannya. Seperti halnya jika terjadi pemadaman listrik, kami tidak menggunakan ginset. Kami akan tetap sebagaimana lazimnya." 52

Dewi Puji Lestari, salah satu santri Pondok Pesantren Raudlotul Ma'rifat mengatakan:

'kami khususnya, saya sendiri senang memasak sendiri, karena banyak hal yang mengesankan. Kesederhanaan ternyata mengajarkan kemandirian. Kami senang melakukan itu. Ngaji juga kadang kita memakai kitab kuning sebagai cara mempertahankan tradisionalnya." 53

Upaya mempertahankan nilai dan pola tradisional menunjukkan bahwa tidak semua pesantren yang mempertahankan tradisionalismenya bukan tanpa alasan. Pondok Pesantren Raudlotul Ma'rifat tidak menghilangkan budaya tradisional pondok pesantren karena seluruh komponen merasa hal tersebutlah yang mampu membuat santri mandiri. Kesederhanaan sejatinya mengajarkan pada kemandirian.

3. Gaya Kepemimpinan Kharismatik

${ }^{51}$ Fathul Huda, Wawancara, Ustadz Pondok Pesantren Roudlotul Ma'rifat, 07 April 2018.

52 Rozy, Wawancara, Ustadz Pondok Pesantren Roudlotul Ma'rifat, 07 April 2018.

${ }^{53}$ Dewi Puji Lestari, Wawancara, Santri Pondok Pesantren Roudlotul Ma'rifat, 07 April 2018. 
Pemimpin adalah seorang yang memiliki kecakapan tertentu yang dapat mempengaruhi para pengikutnya untuk melakukan kerja sama ke arah pencapaian tujuan yang telah ditetapkan. Dengan demikian, jelas bahwa pemimpin sedapat mungkin memiliki berbagai kelebihan, kecakapan dibandingkan dengan anggota lainnya.

Kiai sebagai founding father sebuah pesantren, adalah seorang tokoh yang merintis untuk tegaknya kehidupan yang lebih baik berdasar pandangan hidup yang benar dan jernih sesuai dengan syariat Islam. Itu semua diperolehnya setelah menempuh nilai-nilai utuh dari pemahaman agama Islam yang diyakininya. Amal shaleh yang ia tempuh serta ibadah yang ia jalankan tiada lain hanya berdasar ilmu yang diperoleh dengan bersusah payah.

KH. Ach. Umar Faruq, pendiri Pondok Pesantren Raudlotul Ma'rifat, yang juga pernah menjadi santri yang berawal dari niat belajar agama untuk memperoleh ridho Allah dan daral akhirah, serta untuk menghilangkan kebodohan diri. Saat ini,ia banyak mengasuh jamaah yang berada di basis masyarakat kecil dan pinggiran kota, sesuai dengan harapan untuk menghidupkan agama dan melangsungkan Islam bukan pada dirinya saja namun juga pada orang lain.

Meskipun pendiri pondok pesantren Raudlotul Ma'rifat mempertahankan eksistensi ketradisionalannya, namun bukan berarti pondok pesantren tidak mengikuti kemajuan yang ada. Seperti halnya program-program pembangunan, sudah banyak gedung baru yang dibangun sebagai asrama. KH. Ach. Umar Faruq juga mempunyai daya kharismatik tinggi yang membuat para santri merasa nyaman berada di Pondok Pesantren.

Dalam hal ini, Hendra Setiawan, salah satu santri pondok pesantren Raudlotul Ma'rifat, mengatakan:

'Gus Mama' adalah pengasuh kami, yang membuat kami merasa nyaman. Beliau mempunyai daya kharismatik tinggi. Kami merasa mendapat contoh nyata dalam cara menghadapi hidup dan kehidupan. Kharisma kiai itulah yang membuat santri betah di pondok pesantren, dan kharisma itu pula yang membuat masyarakat tetap mempercayakan pondok pesantren ini sebagai tempat menempa diri." 54

${ }^{54}$ Hendra Setiawan, Wawancara, Santri Pondok Pesantren Roudlotul Ma'rifat, 08 April 2018. 
Dewi Puji Lestari, salah satu santri Pondok Pesantren Raudlotul Ma'rifat, mengatakan bahwasannya:

"yang membuat kami betah disini, salah satu alasannya juga karena selain kami bisa melanjutkan pendidikan meskipun tidak dilanjutkan dengan sekolah, kiai adalah salah satu sosok yang membuat kami merasa nyaman dari auranya dan dari cara beliau memimpin. Apa lagi saat kegiatan pengajian terutama pada kitab Hikam, dari keterangannya hati kami merasa tenang." 55

Khomsin jugamenyampaikan:

“Gus mama' dalam memimpin mempunyai jiwa leadership, enterpreneurship dan spiritualitas. Hal ini yang membuat semua merasa tenang. Proses memberikan ilmu melalui jalan sufistik menimbulkan jalan ketenangan. Karena semua diajari dengan pendekatan hati." 56

Orientasi dari Leadership seseorang sangat berkaitan dengan kepribadian. Kepribadian pemimpin akan tercermin dalam sifat-sifat jujur, percaya diri, tanggung jawab, berani mengambil resiko dan keputusan, berjiwa besar, emosi yang stabil, serta teladan.

Enterpreneurship dihubungkan dengan peningkatan kompetensi tenaga pengajar. Gus Mama' dapat menciptakan pembaharuan, serta memanfaatkan berbagai peluang. Dengan mengajarkan kepada para santri tentang wirausaha sehingga para santri output-nya berjiwa entrepreneur. Spiritualitas artinya nilai keagamaan yang begitu mendalam. Dengan kecerdasan spiritual manusia bisa cerdas secara spiritual dalam beragama, serta dapat meningkatkan nilai spiritual yang dimiliki. Apalagi manusia bisa meningkatkan nilai spiritualnya dengan baik dan menggunakan dalam beragama terutama dalam beribadah kepada allah, dan manusia itu akan menpunyai kebahagiaan dunia dan akhirat. Akan tetapi dalam agenda kecerdasan spiritual ini seharusnya dapat di internalisasikan dan di terapkan kedalam struktur pendidikan. Pendidikam akhlak misalnya, maka dari pendidikan inilah dapat dijadikan jalan untuk menerapakan kecerdasan spiritual secara langsung, sehingga dapat memberikan bekas dan pengaruh yang kuat dalam prilaku santri di Pondok Pesantren dan dalam kehihupan sehari-hari.

55 Lestari, Wawancara, Santri Pondok Pesantren Roudlotul Ma'rifat, 08 April 2018.

56 Khomsin, Wawancara, Ustadz Pondok Pesantren Roudlotul Ma'rifat, 08 April 2018. 
Pada pengamatan peneliti, Gus Mama' memiliki majelis taklim yang diasuh di basis masyarakat. ${ }^{57}$ Khusus santriwan dan santriwati dalam pengajian kitab, berkumpul dalam satu tempat, namun bagi santriwati diwajibkan memakai cadar.

Khomsin juga mengatakan:

'kiai betul-betul mendalami ilmu agama, beliau mempunyai banyak jamaah di luar pondok pesantren yang mengaji kitab hikam, masyarakat menyebutnya dengan pengajian hikaman. Beliau juga membimbing para santri dengan sungguh-sungguh. Riyadhoh juga menjadi pekerjaan wajib yang harus dilakukan oleh santri." 58

4. Jadwal Kegiatan Tidak Terlalu Padat

Pondok Pesantren Raudlotul Ma'rifat adalah salah satu pondok yang terletak di pedalaman desa, tidak ada sekolah formalnya. Yakni tetap mempertahankanpolaSalafiyahnya. Sehingga jadwal kegiatan tidak terlalu padat. Salah satu alasan santri masih bertahan yang mana dengan bertahannya santri bahkan meningkat merupakan objek terpenting dalam mempertahankan eksistensi pesantren.

Nur Farida salah satu santri pondok pesantren Raudlotul Ma'rifat, mengatakan:

'kami kerasan (baca: betah) tinggal disini karena jadwal kegiatan disini tidak terlalu padat. Santri bisa leluasa dengan berbagai aktivitas kemasyarakatan. Kadang kita terlibat dalam pengajian Hikaman yang dilaksanakan oleh kiai bersama dengan masyarakat." 59

Hal yang sama juga dipaparkan oleh Umar, salah satu santri Pondok Pesantren Raudlotul Ma'rifat, ia mengatakan:

"menurut saya pribadi, jadwal disini tidak terlalu padat karena tidak ada formalnya. Meskipun demikian kami betah tinggal disini, karena kami tetap bisa memiliki ijazah yang setara dengan SMP/MTs dan SMA/MA. Sehingga jika kami nantinya mempunyai niat dan keinginan untuk melanjutkan ke sekolah yang jenjangnya lebih tinggi, kami bisa. Dan yang paling penting, bekal mengarungi hidup dengan petunjuk kiai bias didapat."60

57 Observasi, Pondok Pesantren Roudlotul Ma'rifat, 09 April 2018.

${ }^{58}$ Khomsin, Wawancara, Ustadz Pondok Pesantren Roudlotul Ma'rifat, 08 April 2018.

${ }^{59}$ Nur Farida,Wawancara, Ustadz Pondok Pesantren Roudlotul Ma'rifat, 08 April 2018.

${ }^{60}$ Umar, Wawancara, Ustadz Pondok Pesantren Roudlotul Ma'rifat, 08 April 2018. 
Penjelasan di atas mengisyaratkan bahwa salah satu strategi mempertahankan pondok pesantren salafiyah dalam menghadapi era modernisasi adalah mengupayakan santri tetap betah dipondok. Salah satu alasan santri tetap betah di pondok adalah karena jadwal kegiatan yang tidak terlalu padat. Dengan betahnya para santri, juga menjadi salah satu alasan eksistensi pesantren salafiyah ini. Karena santri merupakan objek utama penentu bertahannya sebuah Pondok Pesantren.

Abdul Munir Mulkhan menjelaskan bahwa sekalipun pondok pesantren harus tetap memelihara keasliannya, tetapi untuk dapat mempertahankan keberadaannya, dia harus mau dan mampu mengadakan adaptasi dan integrasi dengan lingkungan yang ada.

\section{Kesimpulan}

Kesimpulan penelitian di atas adalah sebagai berikut:

1. Dalam program pendidikan yang ditawarkan, pesantren memberlakukan beberapa program pendidikan sebagai bentuk penyesuaian dengan kebutuhan masyarakat modern, yakni dengan mengikut sertakan santri persamaan dan paket $C$, serta tetap mengupayakan tidak menghilangkan budaya tradisional.

2. Kurikulum yang diajarkan tetap mengacu pada tradisi klasik, yakni dengan memposisikan kitab-kitab klasik sebagai materi inti dan utama dengan metode tradisional.

3. Aspek lain yang juga menjadi hal penting yakni soal gaya kepemimpinan kiai. Kharisma kiai menjadi hal utama pesantren ini tetap diperhitungkan oleh masyarakat dalam pemilihan pendidikannya.

\section{Referensi}

Abdurrahman, Kasdi. 2002. Fundamentalisme Islam Timur Tengah; Akar Teologi, Kritike Wacana dan Pilotisasi Agama, dalam Tanwir Al Afkar, edisi No. 13.

Abed, Al-Jabiri Muhammad. 2000. Post Tradisionalisme Islam, ter. Abmad Baso, Yogyakarta: LKiS.

Aceh, Abu Bakar. 1982. Sejarah Hidup K.H. A Wabid Hasyim dan Karangan Tersiar, Jakarta: Dharma Bhakti. 
Amin, Haedari, dkk. 2004. Masa Depan Pesantren dalam Tantangan Modernitas dan Tantangan Komplesitas Global, Jakarta: IRD PRESS.

Arifin, HM. 1995. Kapita Selekta Pendidikan Islam dan Umum, Jakarta: Bumi Aksara.

Arifin, Zainal. 2012. Pengembangan Manajemen Mutu Kurikulum Pendidikan Islam, Yogyakarta: DIVA Press.

Azra, Azyumardi. 1985. "Surau di Tengah Krisi: Pesantren dalam Perspektif Masyarakat" dalam M. Dawam Rahardjo, (ed), Pergulatan Dunia Pesantren : Membangun Dari Bawah, Jakarta: P3M.

2012. Penddidikan Islam, Tradisi dan Modernisasi di Tengah Tantangan Millenium III, Jakarta: Kencana Prenada Media Group.

Chirzin, M. Habib. 1988. "Agama dan Ilmu dalam Pesantren”, dalam Pesantren dan Pembaharuan, ed. M. Dawam Rahardjo, Jakarta: LP3ES.

Clifford, Greertz. 2005. "Abangan Santri; Priyayi dalam Masyarakat Jawa", diterjemahkan oleh Aswab Mahasun, Cet. II. Jakarta: Dunia Pusataka Jaya.

Daulay, Haidar Putra. 2001. Historisasi dan Eksistensi Pesantren, Sekolah, dan Madrasah Yogyakarta: Tiara Wacana.

Departemen Agama RI. 2003. Direktorat jenderal kelembagaan Agama Islam Direktorat Pendidikan Keagamaan Pondok Pesantren proyek peningkatan pendidikan luar sekolah pada Pondok Pesantren Pola Pengembangan Pondok pesantren, Jakarta: Departemen Agama RI.

Departemen Pendidikan dan Kebudayaan. 1989. Kamus Besar Bahasa Indonesia, Jakarta: Balai Pustaka.

Departemen Pendidikan Nasional. 2003. Undang - Undang Republik Indonesia Nomor 20.

Deperteman Agama RI. Direktorat Jenderal Kelembagaan Agama Islam, Pondok Pesantren dan Madrasah Diniyah; Pertumbuhan dan Perkembangannya.

Dofier, Zamakhsyari. 2011. Tradisi pesantren: Studi pandangan Hidup Kiai dan Visinya Mengenai Masa Depan Indonesia, Jakarta: LP3ES.

Faiqoh. 2002. Pedoman Pondok Pesantren, Jakarta: Departemen Agama RI.

Faisal, Ismail. 1998. Paradigma Kebudayaan Islam: Study Kritis dan Refleksi Historis, Yogyakarta: Titian Ilahi Press.

Hamid, Abu. 1983. "Sistem Pendidikan Madrasah dan Pesantren di Sul-SeP', dalam Taufik Abdullah (ed), Agama dan Perubahan Sosial, Jakarta: Rajawali Press.

Hasbi, Indra. 2003. Pesantren dan Transformasi Sosial: Studi atas Pemikiran K.H. Abdullah Syafi'ie Dalam Bidang Pendidikan Islam, Jakarta: Pena Madani.

Hasbullah. 1996. Kapita Selekta Pendidikan Islam, Jakarta: PT Raja Grafindo Persada. . 1995. Sejarah Pendidikan Islam di Indonesia, Jakarta: PT. Raja Grafindo. 
Kartono, Kartini. 1996. Metodologi Penelitian Sosial, Bandung: Bumi Aksara.

Kuntowijoyo. 1990. Paradigma Islam Interpretasi Untuk Aksi, Bandung: Mizan. 1990).

Lorens, Bagus. 2005. Kamus Filsafat, Jakarta: Gramedia Pustaka Utama.

Madjid, Nurcholish. 1977. Bilik-bilik Pesantren; Sebuah Potret Perjalanan, Cet. I, Jakarta: Paramadina.

Mahfudh, Sahal. 1999. Nuansa Figh Sosial, Yogyakarta: LKiS. Lihat pula, Pesantren Mencari Makna, Jakarta: Pustaka Ciganjur.

Mahmud. 2006. Model-Model Pembelajaran di Pesantren, Jakarta: Media Nusantara.

Mansur. 2004. Moralitas Pesantren, Yogyakarta: Safiria Insani Press.

Margono, S. 2000. Metodologi Penelitian Pendidikan, Jakarta: Rineka Cipta.

Maryam, Jameelah. 1982. Islam dan Modernisme, Surabaya: Usaha Nasional.

Moeleong, Lexy J. 1994. Metode penelitian kualitatif, Bandung: Remaja Rosda Karya Offest.

Nata, Abuddin. 2005. Tokoh-tokoh Pembaruan Pendidikan Islam di Indonesia, Jakarta: Raja Grafindo.

Noor, Mahpuddin. 2006. Potret Dunia Pesantren, Lintas Sejarah, Perubahan, dan Perkembangan Pondok Pesantren, Bandung: Humanioria.

Nurhadi, Rofiq. 2005. "Sistem Pendidikan Pesantren di Tengah Arus Demokratisasi”, Studi An-Nur, vol. II, No. 3, Yogyakarta

Qomar, Mujamil. Tt. Pesantren dan Transformasi Metodologi Menuju Demokratisasi Institusi, Jakarta: Erlangga.

Ridwan, Nur Kholik. 2008. NU dan Neoliberalisme; Tantangan dan Harapan Menjelang Satu Abad, Yogyakarta: LKiS.

Saleh, Abdul Rahman. 2004. Madrasah dan Pendidikan Anak Bangsa, Visi, Misi dan Aksi, Jakarta: Raja Grafindo.

Seabrook, Jeremy. 2006. Kemiskinan Global; kegagalan Model Ekonomi Neo-Loberalisme, terj. Darmawan, Yogyakarta: Resist Book.

Siradj, Sa'id Aqiel. 1999. Pesantren Masa Depan, Bandung: Pustaka Hidayah.

Soekanto, Soerjono. 1996. Sosiologi Suatu Pengantar, Jakarta: PT. Raja Grafindo Persada.

Subhan, Arief. 2009. Lembaga Pendidikan Islam Indonesia Abad ke-20, Jakarta: UIN Press dan Center for quality Development and Assurance.

Sulthon, Masyhud, dkk. 2005. Manajemen Pesantren, Jakarta: Diva Pustaka.

Sztmpka, Peter. 2005. Sosiologi Perubahan Sosial, terj. Alimandan, Jakarta: Prenada Media. 
Tim Penyusun Kamus Pusat Bahasa. 2001. Kamus Besar Bahasa Indonesia, Jakarta: Balai Pustaka.

Turner, Bryan. 2003. Teori-Teori Sosiologi Modernitas dan Posmodernitas, terj. Imam Baihaqi, Yogyakarta: Pustaka Pelajar.

Wahid, Abdurrahman. 2001. Menggerakekan Tradisi: Esai-Esai Pesantren, Yogyakarta: PT. LKiS.

Wahjoetmo. 1997. Perguruan Tinggi Pesantren Pendidikan Alternatif Masa Depan, Jakarta: Gema Insani Press.

Yasmadi. 2005. Modernisasi Pesantren, Kritik Nurkholis Madjid Terhadap Pendidikan Islam Tradisional, Jakarta: Ciputat Press.

Zahara, Idris. 1992. Pengantar Pendidikan, Jakarta: PT. Gasindo.

Zarkasyi, Abdullah Syukri. 2005. Gontor dan Pembaharuan Pendidikan Pesantren, Jakarta: PT. Raja Grafindo Persada.

Ziemik, Manfred. 1986. Pesantren Dalam Perubahan Sosial terj. Butche B Soendjoyo (Cet: I), Jakarta: P3M. 